\title{
"A Proper House, Not a Barn": House Biographies and Societal Change in Urban Kyrgyzstan
}

\section{Eliza Isabaeva}

A house is a never-finished project:

as a family's wealth, reputation, prestige and membership grows, the house will also grow.

(Osella and Osella 1999, 1018)

\section{Introduction}

In the aftermath of the Tulip Revolution in 2005, the topic of change dominated Kyrgyz society-practically everyone in the country, whether politicians, civil society representatives, or ordinary Kyrgyzstani citizens, was actively discussing the consequences of the Revolution and the future of the country and its people (Nechaev 2005; Shenker 2006). Kyrgyzstan was the first country in the Central Asian region to experience a popular

E. Isabaeva $(\varangle)$

University of Zurich, Zurich, Switzerland

e-mail: eliza.isabaeva@uzh.ch 
revolt, which ended the rule of the country's first president, Askar Akaev, and many in Kyrgyzstan were hoping for positive change. ${ }^{1}$

The Tulip Revolution brought about change in political leadership when Akaev was ousted from office and Kurmanbek Bakiev came to power. While some activists and observers cheered the revolution and had big hopes for wider political change (Olcott 2005), a large number of researchers argued that the revolution did not result in noteworthy changes in the country. For example, Tucker (2007) questions the meaning of the word "revolution" in the Kyrgyz case because "the use of the word 'revolution' is not meant to imply any long-term consequences but rather only to identify that the anti-regime forces were in fact successful in overthrowing the current regime" (2007, 536). Fairbanks (2007) likewise did not expect lasting change because "the Tulip Revolution only replaced one former communist apparatchik with a less sophisticated one, and the northern elite with a more parochial southern elite" $(2007,55)$. In a similar manner, Radnitz called the Kyrgyz revolution "putative" and concluded that it was merely a "transfer of power" (2006, 133), while Tudoroiu $(2007,315)$ spoke of a limited rotation of ruling elites rather than a democratic revolution.

In this chapter, I will move the focus away from these meta-debates about revolution. I do not intend to provide yet another definition of what a revolution is and what it should entail to be called a "real" revolution with "revolutionary" changes. My aim is rather to offer an alternative perspective on the aftermaths of the Tulip revolution by exploring some of the visible and tangible changes that took shape in the lives of ordinary Kyrgyz at the intersection of both institutional transformations and individual agency. In other words, I am interested in the way change is lived and materialized, as well as in the way it is shaped by everyday objects and activities. How did ordinary Kyrgyz perceive and experience the institutional changes triggered by the political transition that followed

\footnotetext{
${ }^{1}$ Akaev had been in power in Kyrgyzstan since the country's independence from the Soviet Union in 1991. By 2005 he had been accused of corruption, nepotism, and strong one-family rule (Lewis 2008). Prior to March 2005, when he was overthrown in the Tulip Revolution, Kyrgyzstan had held parliamentary elections in February in which Akaev's eldest daughter and eldest son were elected to the Kyrgyz Parliament. The opposition in the country feared that the Akaevs would continue to rule without any significant change, and it was important therefore to insist on change.
} 
the revolt of 2005? How did they themselves contribute to producing change in times of unrest and uncertainty?

I will illustrate how these questions can be tackled through the ethnographic study of house biographies. Things or objects that are subject to change have been conceptualized in the literature as having their own lives and biographies (Appadurai 1986; Carsten 2018; Derks 2015; Kopytoff 1986; Osella and Osella 1999). Using the example of houses, I will show how such trajectories can inform us about broader social transformations. First, houses represent tangible and material units of observation that the researcher can visit at different moments of her investigation, thus following the manifold and most often visible transformations they undergo (alterations, renovations, deterioration, extensions, etc.). Second, as shown by several authors, a close relationship exists between persons, their houses, and the valued possessions within them (Carsten 2018; Hoskins 1998; Telle 2007): houses are "inanimate things that come to be socially alive" (Telle 2007, 195). Their social embeddedness makes them ideal sites for the observation of social change. Houses are "embedded in the biographies of their inhabitants and vice versa, they embody the interconnections between individual trajectories, kinship, and the state" (Carsten 2018, 103). Thus, focusing on houses helps reveal the multiple entanglements they present "between the lives and relations that are enacted within them" and also "the historically inflected social and political contexts in which they are situated" (ibid., 103). Third, just as "every person has many biographies" (Kopytoff 1986, 68), biographies of things are likewise multiple. Physical, technical, economic, social, and cultural biographies of things inform us about their constantly changing trajectories. These multiple biographies are not separate but closely interrelated, and when they are carefully studied through observations and descriptions (Barth $1967,661)$ we can get a grasp of a society and societal changes by linking empirical data to wider developments. Thus, focusing on houses as a unit of analysis of change enables us also to connect the micro-level analysis of individual experiences of change to the macro-level of social, political, and economic change.

I seek to illustrate these points more specifically by tracing the post2005 development of houses in the illegal settlement of Ak Jar, which 
is situated just outside the official boundary of the capital city, Bishkek. These houses are significant because they were built in the direct aftermath of the revolution through squatting practices of internal migrants with no private property in Bishkek. I will show that there is a close relationship between houses in $\mathrm{Ak}$ Jar and sociopolitical change in Kyrgyzstan. Like the change in leadership, Ak Jar can be seen as one of the material results of the revolutionary period. Moreover, the mere fact that the Ak Jar residents built and upgraded their houses despite the settlement's illegal status tells us as much about the Kyrgyz government's inability or unwillingness to confront and evict them as about the residents' determination to create houses of their own. Thus, the observation of houses and the changes they undergo throughout their existence in $\mathrm{Ak}$ Jar gives us clues about the lives of their dwellers, the structural conditions in Kyrgyz society and the ways in which people try to make use of and even influence the direction of change through their houses.

In order to illustrate these ideas, I first introduce Ak Jar and its inhabitants and provide an overview of the houses in the settlement. I focus particularly on the house of Chinara and her daughter Meerim with whom I lived during the summer of 2012. Living in this house and visiting it again during two shorter stints of fieldwork in 2013 and 2014, I was able to observe how my host's house was subject to change over the course of time, ${ }^{2}$ and how changes to Chinara's house are related to broader changes in Kyrgyzstan such as ruptures, power struggles, and consolidation during and after the Tulip Revolution.

\section{The Birth of Ak Jar and Its Inhabitants' Concerns}

The birth of Ak Jar is intimately linked to the Tulip Revolution. It popped up on the northern edge of Bishkek in the immediate aftermath of the revolution as the result of unauthorized land squatting. On March

\footnotetext{
${ }^{2}$ Besides participant observation and interviewing Ak Jar residents, I met and discussed the concerns of the settlement dwellers with the settlement's community leaders, high-ranking officials, and NGO representatives and collected secondary sources on the background, demographics as well as infrastructural development of the settlement.
} 
24, 2005, due to massive revolts, the first president, Akaev, had to flee to Moscow. The interim government in Kyrgyzstan held negotiations to identify people to appoint to key state positions, but until the Kyrgyz opposition consolidated itself around Bakiev's candidacy for the presidency, the country found itself in a political vacuum. During this time of political uncertainty and unrest, businesses-mostly malls and private shops-in the center of Bishkek were looted, and the outskirts of the city became a site of illegal land squatting, locally referred to, in Russian, as zakhvat or samozakhvat: (land) grabbing or occupation. The illegal settlement of Ak Jar grew as the result of this form of land squatting.

Prior to 2005, the land where Ak Jar stands today belonged to the Province of Chui and had been leased by Aslanbek Maliev (Mitenko 2011), a former member of the Kyrgyz Parliament, for fifty years. The politician had wanted to build a market complex in Ak Jar, but had never succeeded because the plot was occupied by a small group of people known locally as top bashy (squatters) who were believed to have connections with high-ranking politicians, state officials, and state agencies, from whom they had allegedly received information about what pieces of land in Bishkek and nearby was "vacant." During conversations with $\mathrm{Ak}$ Jar residents, I was told that having occupied Ak Jar after the revolution, the top bashylar (pl.) measured out plots varying in size from 400 to $600 \mathrm{~m}^{2}$ and allocated them first of all to themselves and their immediate family members for free, then to relatives, fellow villagers, and friends for relatively small amounts of money. In the last instance, they sold plots to people who approached them for a piece of land. Today the whereabouts of these top bashylar are largely unknown. People who bought plots from them have no official documents to prove their entitlement to the land except a raspiska, a letter drafted by a top bashy confirming that he or she sold the plot for the requested sum of money. The raspiska, however, has no judicial authority as it is not certified by any state institution such as the State Registry Office.

Despite its illegal status, Ak Jar grew significantly over time. According to official figures, it stands on $1,280,000 \mathrm{~m}^{2}$ of land, and is organized along a main axis crossed by 40 side streets. The settlement includes 1935 construction sites: finished, unfinished, and temporary houses, a mosque, two-car service stations, 19 private grocery stores, and the office of Ak 
Jar's self-governance unit. In 2012, 7240 households were registered in the accounts of Ak Jar's community leaders.

The infrastructure of the settlement has also significantly changed. Initially, when the settlement emerged on this vast territory, it was completely without services: there was no electricity, drinking water, or sanitation for people's basic needs. Mentioning these early days, the residents spoke of "conditions like those of the middle ages," referring to the lack of electricity and dark nights. They criticized the rulers of Kyrgyzstan for their inability to provide water for Ak Jar's population despite Kyrgyzstan's rich water resources. Given the state authorities' neglect of the everyday concerns of Ak Jar's inhabitants, they took care of these problems themselves, each household lighting its house in the evenings by means of a private generator bought at a local bazaar and buying water in bottles and containers for drinking, cooking, and washing. These solutions were very expensive, however, in comparison to state-provided electricity and water.

Despite the poor infrastructure, the lack of state-sanctioned property documents, and the illegal status of the settlement, the residents invested much effort, resources, and time into building and improving their houses. Their properties were constantly changing: houses acquired new roofs, gates, and fences, additional floors, new furniture, etc. This effervescence contrasted greatly with Ak Jar's uncertainty about its legalization and the general assumption that "[p] eople who are not secure in their property rights will not invest labour and other resources in [...] the improvement of their houses built on the land, and the infrastructure of their neighborhood" (Ubink 2009, 7). It was as if -in a context of uncertainty marked by the illegal status of the settlement-the residents tried to impose their presence and create stability and continuity through construction and refurbishing activities. The houses in Ak Jar served as bulwarks against the people's illegal status and provided them with security. They made their houses as comfortable as possible because the outside world offered them no comfort. Furthermore, Ak Jar's inhabitants believed that building and upgrading houses and forming a neatly organized settlement would help accelerate the legalization process and 
save the settlement from demolition. ${ }^{3}$ In other words, by making changes to their houses, they hoped to create permanence, indirectly promoting the legalization of their settlement.

\section{The Houses of Ak Jar: More Than just Bystanders}

Thus, the houses in Ak Jar have been constantly changing since the emergence of the settlement. Initially, my informants in Ak Jar told me, their dwellings were small, simple shacks, but over the course of time they grew bigger and were refurbished, constantly changing their interior and exterior appearance. Some houses changed ownership during this process, but only a very few were abandoned by their owners. They also grew in number: if initially there were just a few scattered houses in the settlement, today Ak Jar is the largest and most densely populated illegal settlement in Bishkek.

When I first came to Ak Jar in February 2012, I was struck by the frenzy of construction that was rapidly transforming the settlement. Wherever I looked, people were busy building houses, improving them, designing interior spaces, and acquiring new furniture and household items. Their activities were evidence that the houses were not static constructions but, as Carsten and Hugh-Jones point out, "dynamic entities" undergoing significant alteration $(1995,37)$.

Most of the houses in Ak Jar were constructed of clay, which served as a cheap building material for many residents. Usually the foundations were laid using cement to make the base solid and strong. Those who could afford to purchase more cement were able to build deeper and more solid foundations. The clay walls stood on these foundations.

\footnotetext{
${ }^{3}$ This resembles what has been observed in other contexts. For example, Aktaş (2013) showed how the Turkish gecekondu dwellers aimed for recognition from the state authorities. In every possible way, they tried to improve their habitat and living situation in gecekondus in order to reach a certain standard of living that would prevent state authorities from demolishing settlements and evicting people (ibid., 179). Similarly, people who live in asentamientos in Buenos Aires try to establish the legality of their settlements through a high level of selforganization that is also in accordance with the state's requirements (van Gelder 2010; van Gelder et al. 2016).
} 
Again, those who could afford to mixed straw into their clay to make it more stable and to keep the house warm; and those who could not afford straw relied solely on clay. Even more crucial was the roof, because in Bishkek it can rain heavily in spring and snow a great deal in winter. Without a roof, clay houses could easily be washed away.

Inside, the walls were usually covered with a whitewashed cement, sand, and water plaster. The same was applied to the outside walls, but only when people had enough money to pay for the relatively expensive cement and sand. Similarly, those with money added a wooden floor, and those without ended up with a clay or cement floor, which was very cold in winter.

I visited many different houses in Ak Jar. In the winter, when I started my fieldwork, most of those that I entered were cold. Since the settlement was not connected to the city or the region's central heating system, the residents heated their houses using coal or electric heaters. However, due to the frequent electricity blackouts the latter often stood unused and gave way to coal. But coal also had its disadvantages, as its heat quickly escaped through the gaps in the walls and the roof, and the smoke gave the whitewashed walls a grayish color. As a result, families with bigger houses lived in only one or two rooms during the winter months, with the rest uninhabitable and kept locked due to the cold.

Although most houses in Ak Jar were simple structures and only contained the most basic utensils and furniture, some were more upscale. At the time of my fieldwork, Ak Jar could be divided into two parts: the houses up to 20th street were bigger, solid constructions, and were painted, roofed, gated, and fenced, whereas those from the 21 st to 39 th and 40th streets were smaller shacks that were unpainted, ungated, unfenced, and fitted with makeshift flat roofs. Furthermore, basic service infrastructure such as electricity pylons and wells had not reached the very end of the settlement, and the people in the upper parts of $\mathrm{Ak}$ Jar had to derive their electricity and water from the lower parts of the settlement (Fig. 7.1).

Many people in Ak Jar, especially those who owned small simple shacks, dreamed of a house made of brick on a high cement foundation. Bricks as building material guarantee more stable and warmer walls than clay. While such a house was a costly and luxurious asset, the 


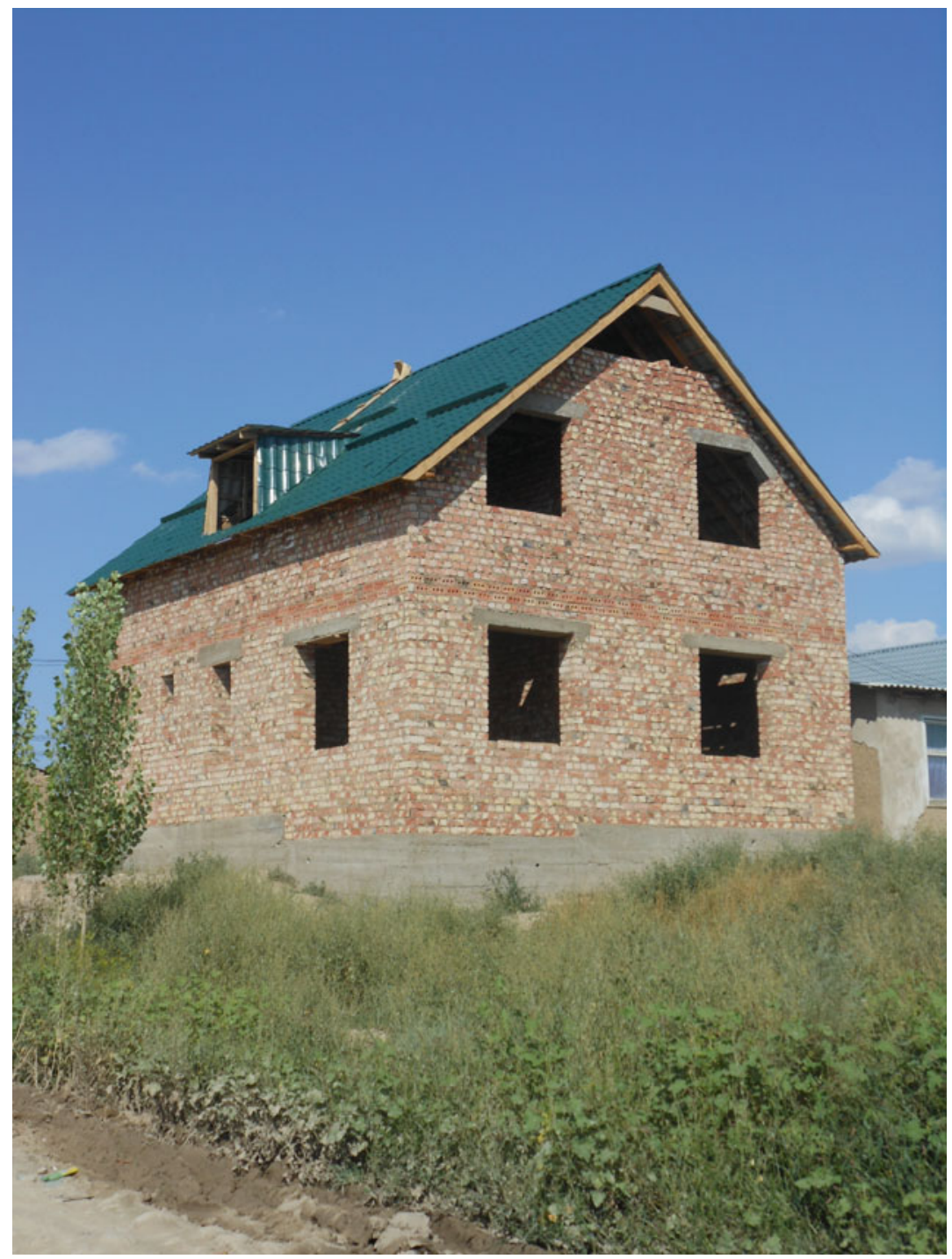

Fig. 7.1 A "proper" brick house (Photo by the author) 
people of Ak Jar aspired to construct or upgrade their existing houses as nearly as they could to these dream houses of brick and cement. Another dream was to have an evroremont (lit. European maintenance) interior. In evroremont houses, the walls were not whitewashed but covered with a smoother plaster, the rooms were large and bright with built-in kitchens, functioning bathrooms, new furniture, and modern electrical devices such as washing machines, color televisions, and large refrigerators.

While most residents of Ak Jar linked their aspirations for the future to these material changes to their houses, it took time, and not many people were able to realize their dreams of home improvement. Below, I describe how the houses were constantly changing by describing the example of the shack of my host, Chinara. Applying the biographical approach, I trace the life of the shack from its early years when she bought it to its coming to maturity with new facilities such as fences, a solid roof, and running water. In addressing each of these changes I relate them to wider developments in Kyrgyz society.

\section{Gradual Change in Chinara's Shack}

\section{2: Early Days in a Dark and Stuffy Room}

Chinara and her 10-year-old daughter Meerim came to live in Ak Jar in 2007. She bought her shack from a top bashy. She said it was in poor condition, uninhabitable, and with no access to electricity or water. With her two elder sons, who at the time of my research lived elsewhere, Chinara painted the inner and outer walls of the shack to make it prettier and more comfortable. They also put a flat roof on the shack, which was less expensive than a peaked one. When I came to live with Chinara and Meerim in 2012, I saw a small shack in front of me. A thick black electricity cable connected it to a neighboring shack on the lower street, which in turn was connected to another neighboring house that was connected to the high-voltage power station. I understood that several households shared electricity. Next to Chinara's shack was a barn in which she kept her fifteen goats and sheep, which provided her with 
milk on a daily basis. The setup of Chinara's shack and barn reminded me of typical rural houses.

Chinara's shack had two rooms. One was still unfinished and was mainly used for storage, and the other served as the living-eating-sleeping room. It had a tiny window and was therefore rather dark. Despite its small size of approximately $14 \mathrm{~m}^{2}$, the room contained an old Sovietstyle cupboard holding dishes, an old sofa, a small fridge, an oven, a small TV, and a dining table. As a result, there was little space for the three of us to move around. Most of the time, Meerim and I sat on the sofa and tried to play games while Chinara watched her evening soap opera.

Despite Chinara's efforts to make the shack a bit more habitable, there were cracks in the walls, holes in the roof, and unfinished corners through which insects got inside. In the summer the room was unbearably hot, and correspondingly in the winter it was severely cold. The floor was made of cement, covered with an old piece of linoleum on top of which Chinara had laid an old carpet. Since the shack was on 36th street, it did not have direct access to power mains or a well. Chinara shared electricity with several other households, which meant that the power was low. As a result, the one room we lived in was almost always only dimly lit. During the day, Chinara would leave the door open so the sunlight would help illuminate the room. Drinking water had to be carried from the well located on the main street. Every evening, Meerim and I went to fetch water, Meerim carrying two smaller buckets and I two bigger ones. We made several trips because we had to fetch water not only for our own consumption but also for the animals. As water was scarce, Chinara refrained from washing the dishes we used for eating.

In $2012 \mathrm{Ak} \mathrm{Jar}$ had already existed as an illegal settlement on the far northern edge of Bishkek for seven years. In the evenings over dinner and tea Chinara recounted stories of how everyday life there was gradually getting better. She was thankful for the electricity and water wells that were delivered to the settlement because she remembered living without these resources. "It was a very difficult time," she would say, sighing heavily. Moreover, she recounted how she had to live with the constant 
threat of eviction and demolition, and how Ak Jar's population mobilized to demand basic infrastructure along with the legalization of their settlement.

Demanding services and legalization from the authorities was not easy for Ak Jar's residents. They wrote numerous letters to state agencies and high-ranking politicians, held peaceful demonstrations in front of the Kyrgyz Parliament and had even staged protests. In their largest street rally in August 2011, they blocked Bishkek's key arterial road for several days, burning tires on it and demanding the arrival of the prime minister and the city mayor. The protest was successful to the extent that it brought important politicians to the people and made them listen. Having heard their concerns, the Prime Minister pledged to resolve their problems. By December 2011 electricity pylons had been installed along the central street and people were able to access electricity. Although this provided power to only part of the settlement, the people were content that in the future the entire settlement would be electrified. They shared this vital resource with one another: households close to the central street connected directly to the main power source and shared with households farther away. The bill that the main electricity-providing household received was equally divided among all the electricity-sharing households. Soon, wells were installed along the central street, freeing people from purchasing drinking water in bottles and containers.

The delivery of these services to Ak Jar was one of the first signs that the settlement might not be demolished in the near future, if ever. Politicians' visits to Ak Jar and their negotiations with the settlement's population showed that the authorities were aware of its existence and of the residents' concerns, de facto turning Ak Jar into a semi-legal settlement. This recognition gave the residents the impression that they were no longer neglected and could make demands on the state, in turn reinforcing their belief that Ak Jar would become legal in the future, making them property owners, and able to remain in Bishkek. 


\section{3: Growing More Solid Through New Acquisitions}

When I returned to Ak Jar in 2013 for a follow-up study, I noticed some major changes to Chinara and Meerim's shack. Whereas the second room was still unfinished, the shack now had a new, "proper" roof made of metal and forming a high peak. ${ }^{4}$ From a distance the high roof automatically changed the physical appearance of the shack, making it taller and more elegant. The roof was one of the first things Chinara talked about when I asked her for the latest news of her household, and of Ak Jar in general, since I had left. She recounted how with financial help from her two older sons she had been able to purchase the necessary materials for the new roof and to hire workers to install it. Listening to Chinara, I could feel her growing confident in her belief that the houses in Ak Jar, especially in the depressed upper part of it where her shack was located, would not be demolished. This was another signal of the permanence of the settlement. Due to this firm belief in its permanence, Chinara's family had invested financial resources in replacing the flat roof with a "proper" peaked one. Furthermore, I realized how the changes to the shack influenced the status of its inhabitants. While its poor condition had made her sons work to save money for the new roof, the construction activity had turned unemployed Chinara into an employer, raising her social status as someone with enough money to hire laborers.

In addition to the new roof, Chinara proudly showed me a new sink in her kitchen-living-sleeping room and told me that she no longer had to carry drinking water. Looking at the sink I realized that the water pressure was not strong because there was a bowl collecting drops from the tap. Nevertheless, the fact that Chinara could now access water directly at home indicated to me that her shack was gradually becoming a house. She told me that Ak Jar's community leadership had negotiated with the state water company to allow residents to pipe water from the central street into their houses at their own cost. Chinara and her neighbors had agreed to raise their own funds and hired someone with a tractor to dig a long trench from the main street to the side street where they lived.

\footnotetext{
${ }^{4}$ The peak-formed roof was particularly useful as it allowed snow and rain to easily run off rather than settling on it as before.
} 
Each household purchased the water pipes and other necessary devices to bring the water directly into their houses. This was a good deal for the water company because people paid for their own extensions, and the company generated more income as the connected households paid more for their water every month than those without direct access to water. This connection to the water mains shows how Chinara and her neighbors grew as a united and cohesive community who could come together to accomplish common goals and believed in the permanence of Ak Jar, and therefore also their houses.

Apart from the new roof and water access, I noticed that everything else had remained the same in the shack. The electricity was still weak and the old furniture was still in the room. However, Chinara informed me that the company responsible for the electrification of Ak Jar was going to install another high-voltage power station in the upper part of the settlement to allow residents there to connect directly to the power source. Furthermore, Chinara wanted to refurbish her shack in the evroremont style. The fact that it was now equipped with a sink, running water and a proper roof meant that her property was already no longer a simple shack. For her neighbors, who could not afford these "luxuries", the shack had become valuable housing and an object of admiration, discussion, and future projection.

Having accessed the essential infrastructure, the residents of Ak Jar now wanted to accelerate their work on the legalization of the settlement and obtain their property documents. There were obstacles to the granting of these, however, because Ak Jar first had to be recognized as a legal settlement. In Ak Jar, when people spoke of legalization, they called it transformatsiia, transformation, implying the transformation of land under the administration of the Province of Chui to land that was part of the municipality of the City of Bishkek, but also the transformation of previously agricultural land into a residential area. During one of the meetings organized by Ak Jar's community leader, Kuban, residents asked him how the transformatsiia was developing. When Kuban told them about the bureaucratic obstacles, one resident demanded in a loud voice, "Shall we block the road again then?" This question reveals many things: obviously, the property documents were of the utmost 
importance to Ak Jar's residents and they were willing to resort to disruptive practices to achieve results, but most importantly, blocking a road would unite a large number of people as a single group in pursuit of a common goal. These expressions of unity and belonging inform us how Ak Jar's residents gradually consolidated power within their settlement through what Asef Bayat (2000) calls "quiet encroachment," in which ordinary people silently advance on the propertied and powerful. Although quiet encroachment implies resistance against the state, the rich, and the powerful, the case of Ak Jar shows how the residents tried to win over the state by demonstrating the harsh conditions in which they lived, thereby hoping to gain its attention and compassion.

As Ak Jar's residents no longer feared demolition, the realization that they had settled permanently became stronger and firmer, giving them even greater incentive to invest in their houses. Thus, the shacks kept growing bigger, becoming more solid, concrete constructions, and some even grew into multistoried brick houses. Although they had not yet been granted their property documents, the residents believed that it would not be long before the transformatsiia was complete. After all, they had raised their own money to help the architecture office draft the master plan (gen plan) of the settlement and they hoped that the state agency would finalize the work. Eventually, the transformatsiia would bring about new changes because it would entail the incorporation of Ak Jar into the city's structure. This would have implications for Bishkek's demography and geography: the city's boundaries would expand and its population would rise.

With the gradual development of Ak Jar's built environment and concomitant increase in population, people's perceptions of the settlement and its dwellers changed. If initially they were stigmatized as squatters, criminals, and lawbreakers, by 2012 the state authorities had negotiated with them on the terms of their inclusion in state structures. Ak Jar's inhabitants argued that they were responsible and contributing citizens because they paid their electricity and water bills every month. Through their aspirations to transform their shacks into big brick evroremont houses, they clearly communicated the message that they valued permanence over transience (Osella and Osella 1999). 


\section{4: Standing Firm—Gated and Fenced}

I returned to Ak Jar in 2014 and straightaway went to visit my hosts. However, I had difficulty finding Chinara's shack. It was difficult to see, hidden as it was behind high iron gates and fences. Moreover, since Chinara's neighbors had also installed gates and fences around their houses, all the houses on the street looked more or less identical. After I had roughly identified the location of my host's house, I spent some time knocking on the iron gate with a stone, as there was no doorbell, hoping to see Chinara and Meerim again. Bothered by the noise I was making, Chinara's neighbor came over to tell me that Chinara had moved to her son's house and no longer lived in the shack, which she now rented to tenants.

Chinara's small shack had been through an interesting trajectory in terms of both its new acquisitions and its new inhabitants. With the new iron gate and the fence around it, the shack now stood as a solid and secure house. In order to enter it, one now had to pass through the gate first. It was no longer directly accessible to visitors as it had been a few years earlier. The fence created some privacy and invisibility for its inhabitants, as neither they nor the shack were exposed for outsiders to see. Furthermore, the gate and fence clearly marked Chinara's territory. Previously, her animals had wandered onto others' properties and Chinara had to endure her neighbors' criticism. Now, the fence prevented the animals from leaving her yard.

In addition to its new material acquisitions over the years, Chinara's shack had also gained new inhabitants, in the form of paying tenants. This meant that there was still strong demand for cheap housing in the city due to continuing internal migration from rural areas. Before settling down in Ak Jar, Chinara herself had rented a shack in a different Bishkek settlement. Becoming a private property owner (albeit still without property documents) meant that she could now rent her shack to others in need of shelter in the city. On the other hand, the fact that internal migrants were still seeking tenancy in illegal settlements such as Ak Jar informs us further about the Kyrgyz government's lack of success with its affordable housing project. Its inability to implement such a project 
obviously had an impact on illegal settlements such as Ak Jar: it meant that they would persist on Bishkek's periphery.

Besides its main function as a shelter for the new family, the shack now also generated income for Chinara in the form of regular rental payments. In times of economic difficulty in Kyrgyzstan, having several properties was helpful for many families. By providing her with a regular income, it could be said that the shack prevented Chinara from becoming a labor migrant in neighboring Kazakhstan or Russia. ${ }^{5}$ Instead she had the privilege of staying at home and still collecting a regular income.

The example of Chinara's shack demonstrates that "objects have histories, careers, social lives [...]" (Derks 2015, 332). Just like a human being purchasing new clothes or accessories, Chinara's shack acquired a new roof, a sink, and new gates and fencing, thereby upgrading itself through Chinara and her sons' efforts. Like a human being who holds different positions and changes functions during his or her career, an object can also change its functions: for instance, the shack went from being Chinara and Meerim's dwelling for many years to becoming a source of income once she moved to her son's house. Having no official employment with a regular salary, the monthly revenue generated by the shack has been a considerable help to Chinara and her family. Witnessing this new development, I recalled how she once told me that she wanted to buy herself a car in order to visit her relatives in neighboring Kazakhstan. I imagined that she would be able to realize this dream in the very near future. In a way, the small shack has allowed her freedom of movement, financial security, and the maintenance of social relations. One could say that the shack has outperformed its original function since the time Chinara first purchased it.

Since the emergence of Ak Jar, the most important milestone in its history has been the delivery of electricity and water infrastructure. This attracted more and more people to the settlement, and so it expanded. In 2012, I counted 37 side streets; a year later I saw scattered houses along a

\footnotetext{
${ }^{5}$ Due to economic hardship in Kyrgyzstan, many people choose to emigrate in search of employment. See Abashin (2014), Isabaeva (2011), Reeves (2012).
} 
new street, 38th street; in 2014, Ak Jar's side streets numbered $39 .{ }^{6}$ Some 15,000 people live in the settlement, and the authorities in Kyrgyzstan seem to have abandoned the idea of demolition or resettlement because the process of its legalization has already started. In the summer of 2018, the speaker at Kyrgyz Parliament informed journalists at a press conference that Parliament had approved a bill for legalizing informal settlements that had emerged on the city's fringes prior to 2009. The bill had been passed to the president to be signed (Radio Azattyk 2018). This means that Ak Jar is just a step away from becoming legal and that it is only a matter of time. Changing their houses and transforming their settlement brought Ak Jar's inhabitants closer to permanence and acted as a way of asserting their rights to the city.

\section{Conclusion}

While Ak Jar's illegal status persists, everything else about the settlement has changed: people move in and move out, houses are being constructed and renovated. The observed transformations inform us about various (interconnected) scales of change: at the individual, the collective, and the national level. At the individual level, the transformations of Chinara's house inform us about her gradual social mobility from illegal and precarious settler, to employer, and later landlord. While her status as illegal resident has not changed, her economic and social situations have clearly improved. This example makes clear how, within the same and seemingly unchanging category of "illegal settler," variations of status can occur.

Second, the gradual improvements of Chinara's shack enable us to analyze how Ak Jar's residents perceive the political changes their country is currently undergoing. Ak Jar's growth and the amount of energy and resources invested in people's houses inform us about the resident's growing confidence in the future and in the expected legalization of the settlement. Moreover, this perception has concrete effects with regard

\footnotetext{
${ }^{6}$ Alymbaeva $(2008,72)$ has documented the similar enlargement of Kelechek settlement, observing the emergence of a new 15 th street there.
} 
to the transformation of the settlement: it contributes to the residents' capacity to organize collectively in order to get access to water and electricity and promotes their desire to resume renovation work in order to impose their presence through material constructions. Some fifteen years after the settlement's sudden emergence on the edge of Bishkek, its residents seem to feel that they have now lived there for a long time. Initially, the authorities' frequent threats of demolition had made it seem imminent, and there was no such feeling of permanence. Gradually, the number of settlement dwellers and houses grew, and therefore became a stronger force when voicing demands for infrastructural improvements and property documents. While electricity and water services have been partially delivered, the residents are still waiting for their property documents, hoping that their wait will not be a long one.

Ak Jar's existence and persistence allowed its dwellers to actively build, renovate, and enlarge their housing. Its emergence and expansion, population growth, and upgrading of houses gradually led to its recognition and inclusion in the city. This very fact led to much broader changes in Bishkek's borders and demography. Agreeing to the transformatsiia-that is, handing over Ak Jar and its population from the jurisdiction of Chui Province to that of Bishkek City-has further demonstrated flexibility with regard to Kyrgyzstan's political governance. Whereas other countries have demolished their illegal settlements, Kyrgyzstan decided first to tolerate and then to accept Ak Jar's illegality. Hence, by changing their houses, Ak Jar's residents actually influenced processes such as urbanization and governance in Kyrgyzstan. All of their activities-upgrading their houses, raising funds, protesting, enduring difficulties, etc.- - are their ways of asserting their rights to the city and participating in shaping it and their own lives (cf. Harvey 2008). When scholars debate whether the Tulip Revolution brought about changes or not, examining the dynamics at the micro-level can help us detect both change and continuity.

Throughout this chapter, I have argued that change can be detected in and studied through objects. Change is processual. Examining objects as a unit of analysis throughout their lifetime/biography enables us to see changes in their usage, functions, careers, and social lives. Ethnographic fieldwork is particularly important here, first of all because it allows a 
researcher time for observation and participation, and second because it connects meta-narratives of change-in this case contradictory narratives about the outcome of the Tulip Revolution-to the researcher's empirical data-in this case, the changes made to Ak Jar's houses. Fieldwork data helps us understand the connection between changes at the micro and the macro-level. By applying a biographical approach to the study of objects, we can see how a particular object changes (houses in Ak Jar were upgraded), how status changes (Ak Jar has gone from existing as an illegal settlement to being a step away from being legalized), how the living conditions of its inhabitants improve, how urbanization processes evolve (Bishkek's shifting borders and increasing population), and how governance/politics transform (Kyrgyzstan tolerating and accepting illegality/informality). Thus, the biographies of the houses of Ak Jar are intrinsically tied to wider developments in Kyrgyzstan.

\section{Bibliography}

Abashin, Sergei. 2014. "Migration from Central Asia to Russia in the New Model of World Order." Russian Politics and Law 52 (6): 8-23.

Aktaş, Sevim. 2013. "The Urbanisation Issue and the Culture of Gecekondus in Turkey." Oriente Moderno 93 (1): 176-87.

Alymbaeva, Aida. 2008. "K voprosu ob urbanizatsii" (To the question on urbanization). Voprosy istorii Kyrgyzstana 1: 65-77.

Appadurai, Arjun, ed. 1986. The Social Life of Things: Commodities in Cultural Perspective. Cambridge: Cambridge University Press.

Barth, Fredrik. 1967. "On the Study of Social Change." American Anthropologist 69 (6): 661-69.

Bayat, Asef. 2000. "From Dangerous Classes to Quiet Rebels: Politics of the Urban Subaltern in the Global South.” International Sociology 15 (3): 53357.

Carsten, Janet. 2018. "House-Lives as Ethnography/Biography." Social Anthropology/Anthropologie Sociale 26 (1): 103-16.

Carsten, Janet, and Stephen Hugh-Jones, eds. 1995. About the House: LéviStrauss and Beyond. Cambridge: Cambridge University Press.

Derks, Annuska. 2015. "Fuelling Change: A Biography of the Beehive Coal Briquette in Post- Đổi Mới Vietnam." Journal of Material Culture 20 (3): 331-49. 
Fairbanks, Charles H. 2007. "Revolution Reconsidered.” Journal of Democracy 18 (1): 42-57.

Harvey, David. 2008. "The Right to the City." New Left Review 53: 23-40. Hoskins, Janet. 1998. Biographical Objects: How Things Tell the Stories of People's Lives. New York: Routledge.

Isabaeva, Eliza. 2011. "Leaving to Enable Others to Remain: Remittances and New Moral Economies of Migration in Southern Kyrgyzstan." Central Asian Survey 30 (3-4): 541-54.

Kopytoff, Igor. 1986. "The Cultural Biography of Things: Commoditization as Process." In The Social Life of Things: Commodities in Cultural Perspective, edited by Arjun Appadurai, 70-73. Cambridge: Cambridge University Press.

Lewis, David. 2008. "The Dynamics of Regime Change: Domestic and International Factors in the "Tulip Revolution." Central Asian Survey 27 (3-4): 265-77.

Mitenko, Pavel. 2011. "Gde nochuet kirgizskaia revoliutsia." Ferghana Information Agency, March 11. https://www.fergananews.com/articles/6917? \&fro mnews=1. Accessed July 10, 2019.

Nechaev, Gennady. 2005. "Chto ozhidaet Kirgiziiu. Vzgliad - delovaia gazeta." Newspaper Vzgliad, August 13. https://vz.ru/politics/2005/8/13/3739.print. html. Accessed July 10, 2019.

Olcott, Martha Brill. 2005. "Kyrgyzstan's 'Tulip Revolution'." Carnegie Endowment for International Peace, March 28. http://carnegieendowment. org/2005/03/28/kyrgyzstan-s-tulip-revolution-pub-16710. Accessed July 10, 2019.

Osella, Filippo and Caroline Osella. 1999. "From Transience to Immanence: Consumption, Life-cycle and Social Mobility in Kerala, South India." Modern Asian Studies 33 (4): 989-1020.

Radio Azattyk [author unidentified]. 2018. "Kak otrabotal parliament? Spiker i obshestvennost' podvodiat itogi." Radio Azattyk, June 29. https:// rus.azattyk.org/a/kyrgyzstan-parliament-results/29327943.html. Accessed September 10, 2018.

Radnitz, Scott. 2006. "What Really Happened in Kyrgyzstan." Journal of Democracy 13 (2): 132-46.

Reeves, Madeleine. 2012. "Black Work, Green Money: Remittances, Ritual, and Domestic Economies in Southern Kyrgyzstan." Slavic Review 71 (1): 108-34.

Shenker, Sarah. 2006. "Kyrgyz Uprising 'No Revolution.” BBC News, March 23. http://news.bbc.co.uk/2/hi/asia-pacific/4836916.stm. Accessed July 10, 2019. 
Telle, Kari. 2007. "Entangled Biographies: Rebuilding a Sasak House.” Ethnos 72 (2): 195-218.

Tucker, Joshua A. 2007. "Enough! Electoral Fraud, Collective Action Problems, and Post-Communist Colored Revolutions." Perspectives on Politics 5 (3): 535-51.

Tudoroiu, Theodor. 2007. "Rose, Orange and Tulip: The Failed Post-Soviet Revolutions." Communist and Post-Communist Studies 40: 315-42.

Ubink, Janine M. 2009. "Legalising Land Rights in Africa, Asia and Latin America: An Introduction.” In Legalising Land Rights: Local Practices, State Responses and Tenure Security in Africa, Asia and Latin America, edited by Janine M. Ubink, André J. Hoekema, and Willem J. Assies. Leiden: Leiden University Press.

Van Gelder, Jean-Louis. 2010. "Tales of Deviance and Control: On Space, Rules, and Law in Squatter Settlements." Law \& Society Review 44 (2): 239-68.

Van Gelder, Jean-Louis, Maria Cristina Cravino, and Fernando Ostuni. 2016. "Housing Informality in Buenos Aires: Past, Present and Future?" Urban Studies 53 (9): 1958-75.

Open Access This chapter is licensed under the terms of the Creative Commons Attribution 4.0 International License (http://creativecommons.org/ licenses/by/4.0/), which permits use, sharing, adaptation, distribution and reproduction in any medium or format, as long as you give appropriate credit to the original author(s) and the source, provide a link to the Creative Commons license and indicate if changes were made.

The images or other third party material in this chapter are included in the chapter's Creative Commons license, unless indicated otherwise in a credit line to the material. If material is not included in the chapter's Creative Commons license and your intended use is not permitted by statutory regulation or exceeds the permitted use, you will need to obtain permission directly from the copyright holder. 